\title{
Bronowski: the complex life of a science popularizer
}

\section{David Edgerton parses a biography of a polymath and star of 1970s broadcasting.}

$\mathrm{F}$ Tor millions of people in the 1970s, the name Jacob Bronowski was synonymous with science. The Polish-born mathematician arrived in London in 1920, at the age of 12. More than half a century later, his finest hour came with the 1973 television series The Ascent of Man, made by the BBC. Aiming to trace what art historian Kenneth Clark did not in his 1969 series Civilisation, Bronowski's programme was a long look at the development of society through a scientific lens. It was followed that year by a book of the same name.

Now, Timothy Sandefur, an adjunct scholar at the libertarian think tank the Cato Institute in Washington DC, makes great claims in The Ascent of Jacob Bronowski. Sandefur describes him as more than a mere polymath, suggesting that he "was involved with nearly every major intellectual undertaking of the twentieth century"; that he was a "serious philosopher" who made "probably the finest documentary film ever made".

Up to a point. There were more Renaissance men (and inequality meant that all too many were men) in the twentieth century than one can shake one's specialist fist at. Just among British mathematicianphilosophers, Bertrand Russell and Alfred North Whitehead were more significant in both fields than Bronowski. Chemist Michael Polanyi's philosophical works, notably Personal Knowledge (1958), were in a different league from Bronowski's mushy apologias, such as The Common Sense of Science (1951). And at best, The Ascent of Man might be among the top television science documentaries.

Yet Bronowski is interesting for what he was: a scientist and administrator, and a major popularizer of science.

\section{FROM CAMBRIDGE TO COAL}

Bronowski had a remarkably varied career as an academic and state-employed scientist. After graduating from the University of Cambridge, he taught at University College Hull in northern England from 1934 to 1943. For the next six years, he worked as a scientific civil servant. He conducted classified research on saturation bombing for the Royal Air Force during the Second World War, and travelled to Japan to document the effects of the Hiroshima and Nagasaki

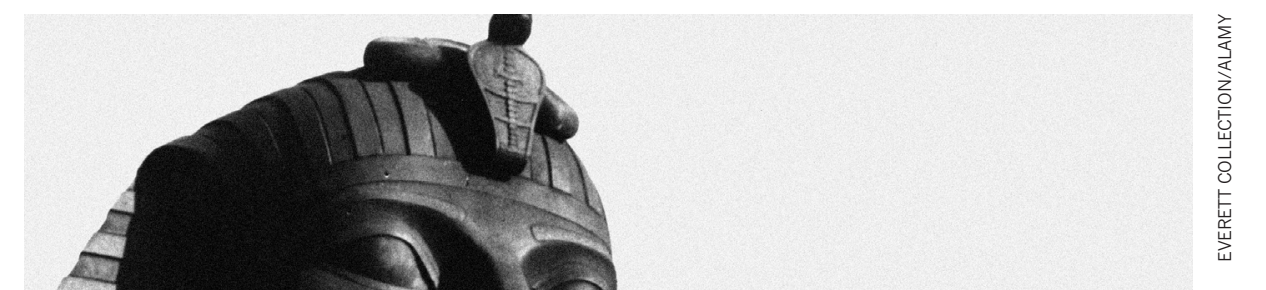


bombings. After the war, he worked on house-building techniques: affordable construction was crucial, not least because of the destruction caused by the Blitz. He had a brief stint at the United Nations Educational, Scientific and Cultural Organization (UNESCO) in Paris; then, from around 1950 to 1964, he became director of the British National Coal Board's new central research facility, where he focused on a project to make fuel briquettes from coal dust (not, as Sandefur implies, the first smokeless fuel). It was not a success. In the late 1950s and early 1960s, he engaged minimally in discussions of science policy.

Bronowski can also stand as one of many British figures who straddled the worlds of science and letters (refuting the claim by chemist and novelist C. P. Snow that there was an unbridgeable divide between the "two cultures", as Snow called them.) In the 1930s and into the early years of the war, Bronowski was, like many intellectuals then, a committed leftist. A poet, he published $A$ Man Without a Mask (1944), an admired study of the extraordinary English poet, artist and engraver William Blake. Sandefur's book is at its best when describing Bronowski's relations with other poets in the 1930s, such as Robert Graves and William Empson (like him, a mathematician).

\section{MEDIA EXPOSURE}

After the war, alongside his career as an operational researcher and scientific administrator, Bronowski became famous thanks to the BBC. He got his start giving talks on the after-effects of the bombings in Japan, and went on to appear on radio and television panel show The Brains Trust, as well as writing plays and giving radio talks. His distinctive mispronunciation of the letter R helped make him memorable. Out of these broadcasts, his work at UNESCO and a guest lectureship at the Massachusetts Institute of Technology in Cambridge came books such as Science and Human Values (1965). Essentially, these were defensive accounts of science and scientists at a time when research was highly militarized, and discussion of science was very much caught up in the ideological struggles of the cold war.

His last years were spent with the Salk Institute for Biological Studies in La Jolla, California, writing about science; this period culminated in The Ascent of Man. The 13-part BBC documentary that made his name covered everything from

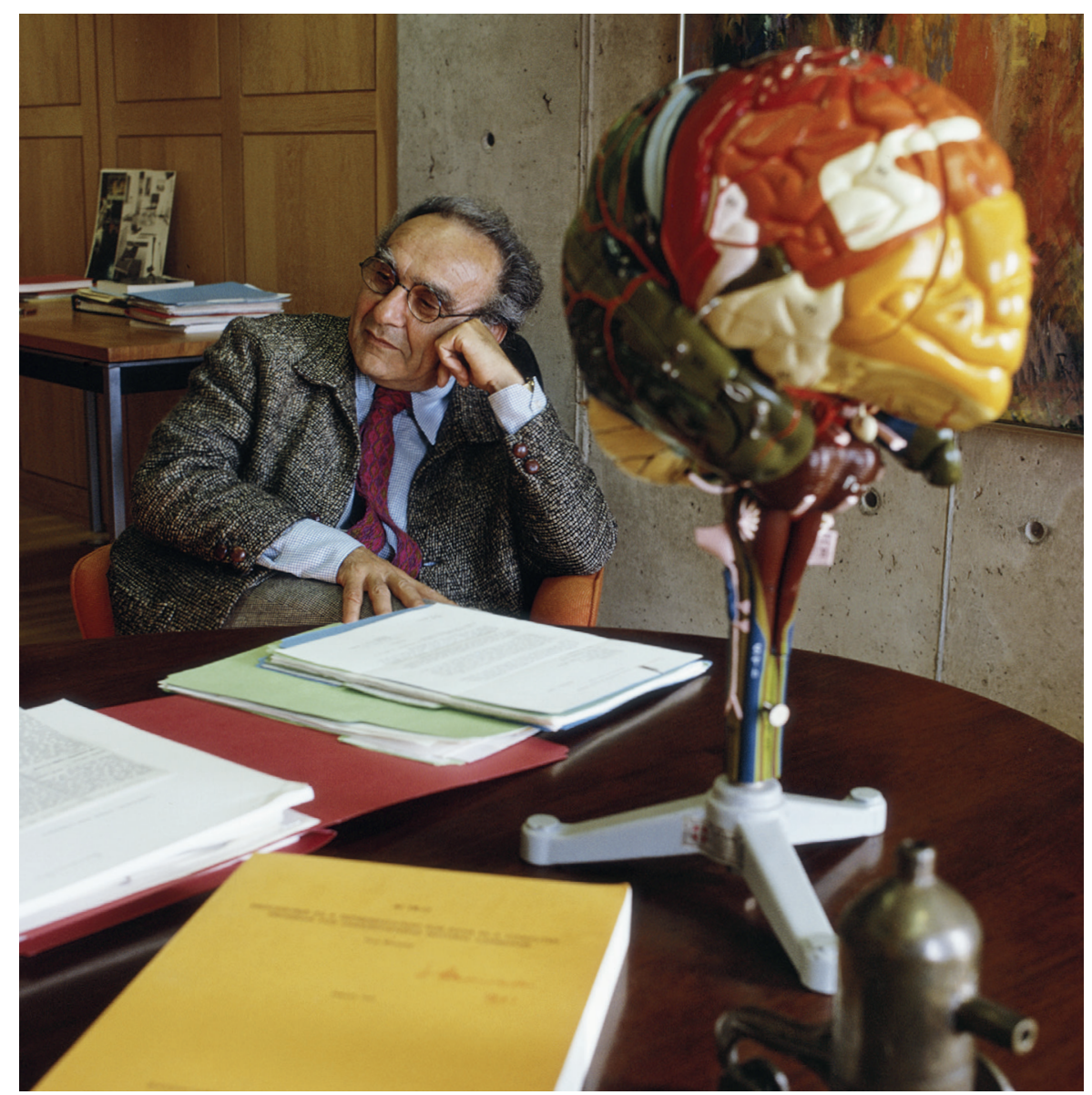

Jacob Bronowski at the Salk Institute for Biological Studies in 1973.

the evolution of humans to cloning. It was notable for its emphasis, in the early programmes, on material things - fire, metal, agriculture, architecture. Lavishly produced and visually stunning, it impressed viewers with its lucidity and with the power of the presenter's personality. Many who saw it still remember it as a landmark in television.

A year after the series ended, in 1974, Bronowski died. One wonders how he managed to pursue two such busy careers. And one can share Bronowski's disappointment that he was never other than a popularizer. $\mathrm{He}$ yearned for a permanent academic position.

Bronowski's books did not generally draw on his own experiences as a scientist. Historian of science Ralph Desmarais was the first to bring Bronowski's war work to light. He showed that Bronowski was consistently less candid about this research than were most wartime scientists, such as experimental physicist Patrick Blackett (R. Desmarais Br. J. Hist. Sci. 45, 573-589; 2012). (Full disclosure: I supervised Desmarais's PhD.)

Desmarais has also revealed that Bronowski was keen to deny the fact that, in the 1940s and early 1950s, Britain was building an atomic bomb while extravagantly promoting civil nuclear power. Bronowski did not, as Sandefur claims, campaign against nuclear weapons. Indeed, his discussion of the overall history of the atomic bomb in The
Ascent of Man was thoroughly misleading. To distance scientists from the weapon, he focused on physicist Leo Szilard, a peripheral figure in the bomb effort who argued that Japan should be shown the power of the bomb, rather than being attacked with it.

His analysis of the relationship between science, the military and power was persistently disingenuous. Desmarais argues compellingly that Bronowski was unable to tell a straightforward story about the place of science in the modern world. Unfortunately, Sandefur does not do justice to this important claim, and his book often becomes an apologia for an apologist.

That is a shame. A properly critical biography of Bronowski, a 1930s radical who became a go-to spokesperson for science, could have had much to teach us about the realities of research in the twentieth century, and the very different registers in which it had to be described in the cold war.

David Edgerton is Hans Rausing Professor of the History of Science and Technology at King's College London, where he teaches in the department of history. His most recent book is The Rise and Fall of the British Nation. e-mail:david.edgerton@kcl.ac.uk

The author declares competing interests: see go.nature.com/2rz5cei for details. 